\title{
Clinical Evaluation of Acupuncture as Treatment for Complications of Cerebrovascular Accidents: A Randomized, Sham-Controlled, Subject- and Assessor-Blind Trial
}

\author{
Hsien-Yin Liao, ${ }^{1,2}$ Wen-Chao Ho, ${ }^{3}$ Chun-Chung Chen, ${ }^{4,5}$ Jaung-Geng Lin, ${ }^{4}$ \\ Chia-chi Chang, ${ }^{2}$ Liang-Yu Chen, ${ }^{2}$ De-Chih Lee, ${ }^{6}$ and Yu-Chen Lee ${ }^{1,2,7}$ \\ ${ }^{1}$ College of Chinese Medicine, Graduate Institute of Acupuncture Science, China Medical University, Taichung 404, Taiwan \\ ${ }^{2}$ Department of Acupuncture, China Medical University Hospital, Taichung 404, Taiwan \\ ${ }^{3}$ Department of Public Health, China Medical University, Taichung 404, Taiwan \\ ${ }^{4}$ College of Chinese Medicine, China Medical University, Taichung 404, Taiwan \\ ${ }^{5}$ Department of Neurosurgery, China Medical University Hospital, Taichung 404, Taiwan \\ ${ }^{6}$ Department of Information Management, Da-Yeh University, Changhua 500, Taiwan \\ ${ }^{7}$ Research Center for Chinese Medicine \& Acupuncture, China Medical University, Taichung 404, Taiwan
}

Correspondence should be addressed to Yu-Chen Lee; d5167@mail.cmuh.org.tw

Received 25 December 2016; Accepted 5 March 2017; Published 20 March 2017

Academic Editor: Jenny M. Wilkinson

Copyright (C) 2017 Hsien-Yin Liao et al. This is an open access article distributed under the Creative Commons Attribution License, which permits unrestricted use, distribution, and reproduction in any medium, provided the original work is properly cited.

Background and Purpose. The effect of acupuncture as treatment for poststroke complications is questionable. We performed a randomized, sham-controlled double-blind study to investigate it. Methods. Patients with first-time acute stroke were randomized to receive 24 sessions of either real or sham acupuncture during an eight-week period. The primary outcome measure was change in National Institute of Health Stroke Scale (NIHSS) score. Secondary outcome measures included changes in Barthel Index (BI), Instrumental Activities of Daily Living (IADL), Hamilton Depression Rating Scale (HAM-D), and Visual Analogue Scale (VAS) for pain scores. Results. Of the 52 patients who were randomized to receive acupuncture $(n=28)$ or placebo $(n=24)$, 10 patients in the acupuncture group and 9 patients in the placebo group failed to complete the treatment. In total, 18 patients in the acupuncture group and 15 patients in the control group completed the treatment course. Reduction in pain was significantly greater in the acupuncture group than in the control group ( $p$ value $=0.04$ ). There were no significant differences in the other measures between the two groups. Conclusions. Acupuncture provided more effective poststroke pain relief than sham acupuncture treatment. However, acupuncture had no better effect on neurological, functional, and psychological improvement.

\section{Introduction}

Stroke is one of the most common causes of death and the leading cause of biopsychosocial disability worldwide. Poststroke complications such as death, loss of motor function, daily life dysfunction, depression, and shoulder pain are common [1]. Although intra-arterial thrombolysis [2], intravenous tissue plasminogen activator [3,4], and other advanced therapies [5] can reduce the incidence of serious postcomplications when performed within the first few hours of symptom onset, no single therapy has been shown to prevent all complications.
Acupuncture is commonly used in Asian countries to manage poststroke complications, and numerous studies on its effectiveness have been conducted. However, the efficacy of acupuncture as treatment for stroke-related complications has been questioned because only a limited number of welldesigned clinical trials have been published. For example, in a recent meta-analysis of eight randomized controlled trials, Park et al. found that the methodological quality of those trials was inadequate to determine the efficacy of acupuncture as treatment for spasticity after stroke [6]. Other meta-analyses have concluded that acupuncture has no beneficial effect on poststroke paralysis $[7,8]$. However, some analyses have 


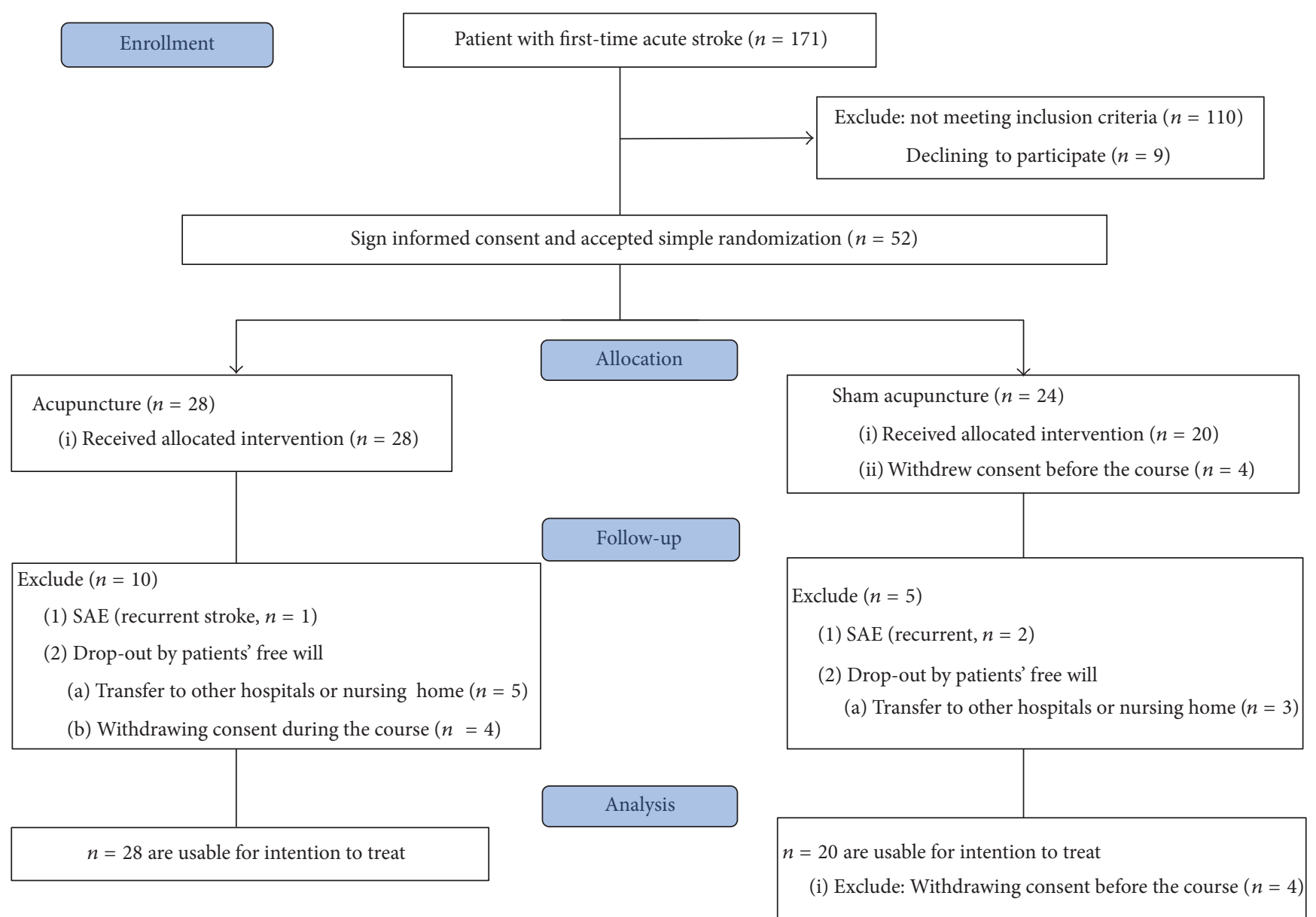

FIgURE 1: Flow diagram of patient screening in this study.

demonstrated that acupuncture can improve cognitive function and decrease depressive symptoms after stroke $[9,10]$.

Few studies have employed well-designed protocol or well-established scales to qualitatively measure the effect of acupuncture on biopsychosocial complications after stroke. We, therefore, designed a subject- and assessor-blinded, randomized sham-controlled clinical trial to assess whether acupuncture is an efficacious treatment modality for poststroke neurologic symptoms using the National Institute of Health Stroke Scale, activities of daily living using the Barthel Index and Instrumental Activities of Daily Living Scale, depressive symptoms using the Hamilton Depression Rating scale, and pain severity using the Visual Analogue Scale in patients with recent first-time stroke.

\section{Methods}

2.1. Ethics. The study was conducted in accordance with the Declaration of Helsinki. The study was approved by the Research Ethics Committee of the China Medical University Hospital, Taichung, Taiwan (Protocol ID: CMUH102-REC2015). The study was also registered on ClinicalTrials.gov before commencement (NCT02197663).
2.2. Study Design. This was a randomized, sham-controlled, subject- and assessor-blind, single-center exploratory clinical trial to investigate the efficacy of 24 sessions of acupuncture as treatment for complications associated with cerebrovascular accidents. A flowchart outlining patient selection and randomization procedures is shown in Figure 1.

2.3. Participants. We had an interview with new stroke patients. During these talks, we checked their response. If patients were unable to cooperate or follow directions for the assessments and tests of our study, they were excluded. Other patients who met the inclusion criteria were given full details of the study in both oral and written form. If the patients agreed to join our study, they needed to sign the informed consent before the beginning of the study. If they were handicapped with limbs weakness, the procedure of signature could be helped by their family.

All patients with first-time incident stroke who were admitted to the Neurological, Neurosurgical, Physical Medicine and Rehabilitation, or Chinese Medicine Departments at the China Medical University Hospital were considered eligible for recruitment. A diagnosis of first-time and recent (1 2 weeks) stroke was based on clinical findings and definitive 
brain computed tomographic (CT) or magnetic resonance (MR) imaging evidence of ischemic or hemorrhagic stroke. Patients were excluded from participating in the study if they had a history of previous stroke or a history of other serious diseases such as cancer, dementia, heart failure, chronic obstructive pulmonary disease, liver cirrhosis, or kidney failure.

After western physicians confirmed that the vital signs of new stroke patients were relatively stable, both randomization and first-time intervention were conducted within one week after stroke was diagnosed.

2.4. Sample Size. The sample size was determined based on an effect size of $d=0.833$ to detect significance of the intervention effect on the primary outcome measure, namely, change in NIHSS score, as described previously [11]. If we permitted a $5 \%$ chance of type I error $(\alpha=0.05)$, a $20 \%$ chance of type II error $(\beta=0.2)$, and a $20 \%$ drop-out rate, then approximately 30 initial participants in each group would be required to have a sufficient sample size. All calculations were performed with $\mathrm{G}^{*}$ power for Windows (Version 3.1, Free Software, Düsseldorf, Germany).

2.5. Randomization. Patients were allocated to receive real acupuncture or sham acupuncture following the principle of simple randomization. Lots with numbers 1 60 were placed into a sealed envelope and participants were asked to draw one without looking at the number. Patients who drew an even number were allocated to the treatment group and those who drew an odd number were allocated to the sham acupuncture group. Only one investigator who was not involved in the treatment, assessment, or data analysis could see the number on the lots. The patients, the assessor, and biostatistician were blinded to the allocation until the data were analyzed.

2.6. Intervention Group (Acupuncture). A single practitioner of Chinese Medicine with more than 15 years of experience in acupuncture performed all of the interventions. Manual acupuncture was carried out in patients in the supine position and comprised both body and scalp acupuncture for a total of 20 minutes per session 3 times per week for a total of 24 sessions. The following acupoints were needled in all patients: Baihui (GV-20), Sishencong (EX-HN1), temporal threeneedle technique (Jin three-needle therapy, one side for the weakness limbs), Quchi (LI11), Hegu (LI4), Neiguan (PC6), Waiguan (TE5), Yanglingquan (GB34), Zusanli (ST36), Sanyinjiao (SP6), and Taichong (LR3). Other acupoints were needled based on each patient's symptoms, such as Speech II or Speech III areas (Jiao's Scalp Acupuncture) for aphasia, Jinjin (EX-HN 12) and Yuye (EX-HN 13) for dysarthria, and Fenglung (ST40) and Chizexue (LU5) for sputum. Each acupoint was stimulated to elicit a needle sensation (de qi) and needling depth was based on the excitation of de qi. All procedures were carried out with disposable needles measuring $0.25 \mathrm{~mm}$ in diameter (32-gauge) and $44 \mathrm{~mm}$ in length (Yu Kuang, Taipei, Taiwan).
2.7. Control Group (Sham Acupuncture). Participants in the sham group also received 24 sessions of acupuncture treatment; however, needling was performed $1 \mathrm{~cm}$ away from the real acupoints. In addition, none of the participants in the sham group received scalp acupuncture. All procedures were carried out to a depth of $0.5 \mathrm{~cm}$ with disposable needles measuring $0.16 \mathrm{~mm}$ in diameter (40-gauge) and $12.7 \mathrm{~mm}$ in length (Yu Kuang, Taipei, Taiwan). No needle sensation (de qi) was elicited.

Patients in both groups also received conventional western rehabilitation with the same frequency and received western medications as needed during inpatient admission and outpatient tracking.

2.8. Outcome Measures. Assessments were carried out before treatment (baseline) and at the end of the 8th, 16th, and 24th treatment session by a single trained, certified, and blinded resident physician.

2.9. Primary Outcome Measure. The primary outcome was change in the National Institute of Health Stroke Scale (NIHSS), a well-established measure of stroke severity.

2.10. Secondary. Secondary outcome measures included changes in Barthel Index (BI, Mahoney and Barthel Version), Instrumental Activities of Daily Living (IADL, Lawton, M. P., \& Brody, E. Version), Hamilton Depression Rating Scale (HAM-D, 24-item Version), and Visual Analogue Scale for pain (VAS) scores. We used the VAS to assess the severity of pain caused by muscle spasticity, limbs hemiplegia, and hemiparesis. Severity of central poststroke pain such as burning, throbbing, or shooting pain was not assessed.

2.11. Incidence of Severe Adverse Events. The majority of potential acupuncture-related adverse events are not lifethreatening and have documented low incidence rates such as local bleeding $(<1 \%)$, haematoma $(<3 \%)$, dizziness $(<1 \%)$, fainting $(<1 \%)$, and pain $(<10 \%)[11,12]$. Therefore, in this study, only major adverse events such as recurrent stroke were included in the analysis.

2.12. Statistical Analysis. Baseline characteristics are expressed as mean \pm standard deviation for continuous variables or as percentages for categorical variables. The chi-square test was used for categorical comparisons of data. Between-group differences in primary and secondary outcome measures are expressed as mean \pm standard deviation and were tested by the Mann-Whitney $U$ test. For within-group comparisons, the Wilcoxon signed-rank test was used. A $p$ value $<0.05$ was considered to indicate statistical significance. All statistical analyses were carried out using the statistical package SPSS for Windows (Version 21.0, SPSS, Chicago, Illinois, USA).

The analyses were performed on an intention-to-treat basis, with missing data replaced by the principle of last observation carried forward. 
TABLE 1: Baseline characteristics of randomized subjects.

\begin{tabular}{|c|c|c|c|}
\hline & Acupuncture $(n=28)$ & Sham acupuncture $(n=20)$ & $p$ value \\
\hline Male, $n(\%)$ & $19(67.86 \%)$ & $11(55.00 \%)$ & \multirow{2}{*}{0.385} \\
\hline Female, $n(\%)$ & $9(33.33 \%)$ & $9(45.00 \%)$ & \\
\hline Image finding: infarct, $n(\%)$ & $14(50 \%)$ & $17(80 \%)$ & \multirow{2}{*}{$0.016^{*}$} \\
\hline Image finding: hemorrhage, $n(\%)$ & $14(50 \%)$ & $3(20 \%)$ & \\
\hline Hypertension, $n(\%)$ & $22(78.57 \%)$ & $13(65.00 \%)$ & 0.34 \\
\hline Diabetes, $n(\%)$ & $5(17.86 \%)$ & $6(30.00 \%)$ & 0.49 \\
\hline Heart disease, $n(\%)$ & $5(17.86 \%)$ & $4(13.30 \%)$ & 1.00 \\
\hline Hyperlipidemia, $n(\%)$ & $0(0.00 \%)$ & $1(5.00 \%)$ & 0.42 \\
\hline Age $($ mean $\pm S D)$ & $62.29 \pm 12.33$ & $55.45 \pm 15.22$ & 0.09 \\
\hline Height (mean \pm SD) & $162.36 \pm 7.58$ & $163.03 \pm 8.50$ & 0.78 \\
\hline Weight $($ mean \pm SD) & $64.56 \pm 9.67$ & $68.84 \pm 11.95$ & 0.18 \\
\hline $\begin{array}{l}\text { Prescore of Barthel Index (mean } \pm \\
\text { SD) }\end{array}$ & $59.64 \pm 41.94$ & $65.75 \pm 34.08$ & 0.93 \\
\hline $\begin{array}{l}\text { Prescore of Instrumental Activities } \\
\text { of Daily Living (male) (mean } \pm \text { SD) }\end{array}$ & $2.63 \pm 2.52$ & $2.55 \pm 2.21$ & 1.00 \\
\hline $\begin{array}{l}\text { Prescore of Instrumental Activities } \\
\text { of Daily Living (female) (mean } \pm \\
\text { SD) }\end{array}$ & $3.8 \pm 3.5$ & $3.4 \pm 2.5$ & 1.00 \\
\hline $\begin{array}{l}\text { Prescore of National Institutes of } \\
\text { Health Stroke Scale (mean } \pm \text { SD) }\end{array}$ & $6.00 \pm 5.84$ & $6.93 \pm 5.75$ & 0.22 \\
\hline $\begin{array}{l}\text { Prescore of Hamilton Depression } \\
\text { Rating Scale (mean } \pm \text { SD) }\end{array}$ & $13.94 \pm 11.27$ & $12.6 \pm 6.34$ & 0.62 \\
\hline $\begin{array}{l}\text { Prescore of Visual Analogue Scale } \\
\text { for pain }(\text { mean } \pm S D)\end{array}$ & $1.56 \pm 2.97$ & $1.47 \pm 2.29$ & 0.68 \\
\hline
\end{tabular}

\section{Results}

3.1. Recruitment and Severe Adverse Events. Figure 1 summarizes the patient selection, recruitment, and exclusion protocols of the trial. Of the 171 patients with first-time stroke who presented to the CMUH during the period June 2014 to October 2015, 61 met the inclusion criteria and 52 of them provided signed informed consent to participate. The 52 patients were randomly assigned to receive real acupuncture $(n=28)$ or sham acupuncture $(n=24)$. However, after allocation, 4 patients in the placebo group withdrew consent to participate and were, therefore, excluded from the analysis. During the 8 -week treatment period, 3 patients were withdrawn from the trial because of recurrent stroke ( 1 in the acupuncture group and 2 in the sham group) and 12 dropped out for personal reasons ( 9 in the acupuncture group and 3 in the sham group), including transfer to other institutions ( $n=5$ and $n=3$, resp.) and withdrawal of consent ( 4 in the acupuncture group). Therefore, 18 patients in the acupuncture group and 15 patients in the sham group completed the treatment course. However, for intention-totreat purposes, data on 28 participants in the acupuncture group and data on 20 participants in the sham group were available for analysis.

3.2. Baseline Data. Baseline data are presented in Table 1. There were no significant differences in baseline characteristics between the two groups of patients with the exception of stroke type. The incidence of ischemic stroke was significantly higher in the sham group than in the acupuncture group and the incidence of hemorrhagic stroke was significantly higher in the acupuncture group than in the sham group.

3.3. Drop-Out Rate and Drop-Out Data Analysis. As seen in Figure 1, the drop-out rates were $32.14 \%$ (9/28) in the acupuncture group and $29.17 \%(7 / 24)$ in the sham group. No one dropped out due to the design or execution of the trial.

3.4. Primary and Secondary Outcome Measures. By analyzing the data after 8 th and 16th treatment sessions, we found no significant between-group differences and decided to present the data of baseline and the end.

As shown in Figures 2(a), 2(b), and 3(a), intragroup comparisons revealed that both acupuncture group and sham acupuncture group had significant improvements in NIHSS, Barthel Index, and HAM-D scores. However, there were no significant differences in improvement in scores between the two groups.

As shown in Figure 2(c), there were no significant intergroup or intragroup differences in scores on the IADL scale. Interestingly, however, significant intragroup improvement in IADL scale was noted for women who received sham acupuncture.

As shown in Figure 3(b), reduction in pain was significantly greater in the acupuncture group than in the control group $(p=0.04)$.

Whole results of all scales were shown as Table 2. 


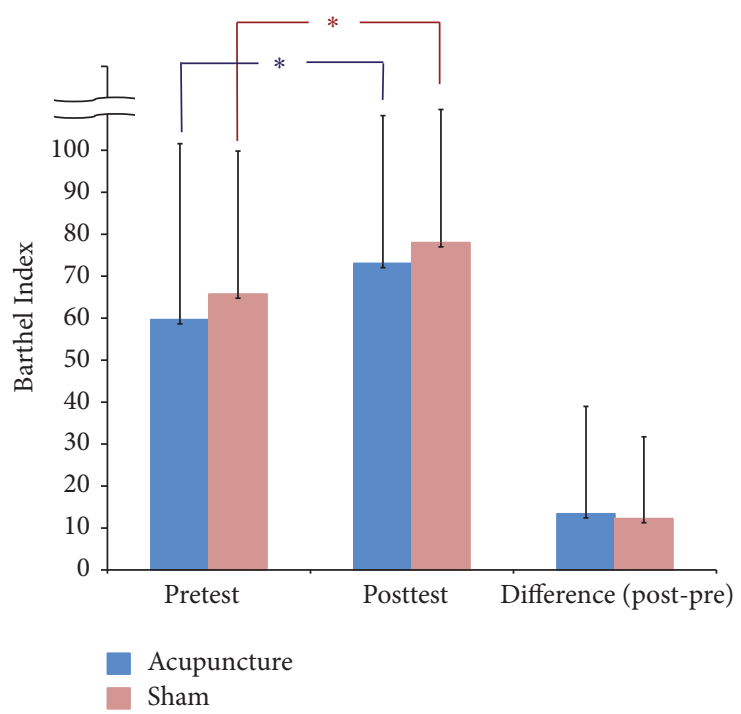

(a)

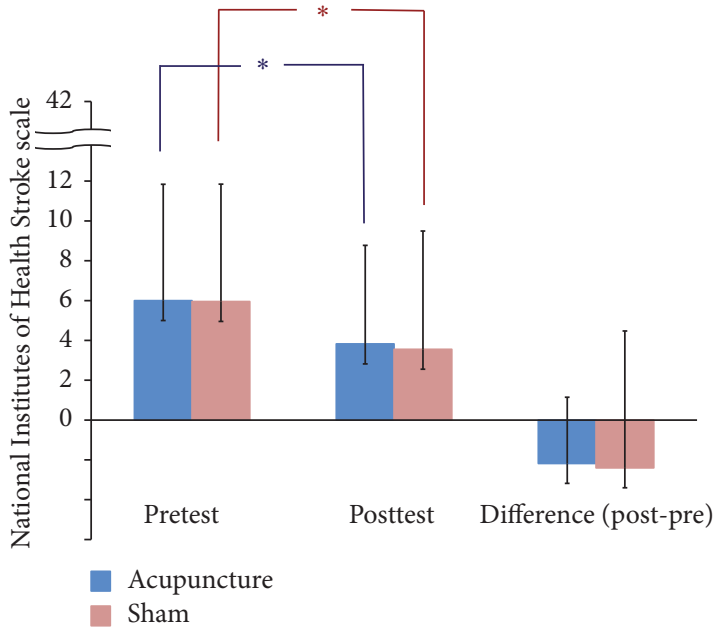

(b)

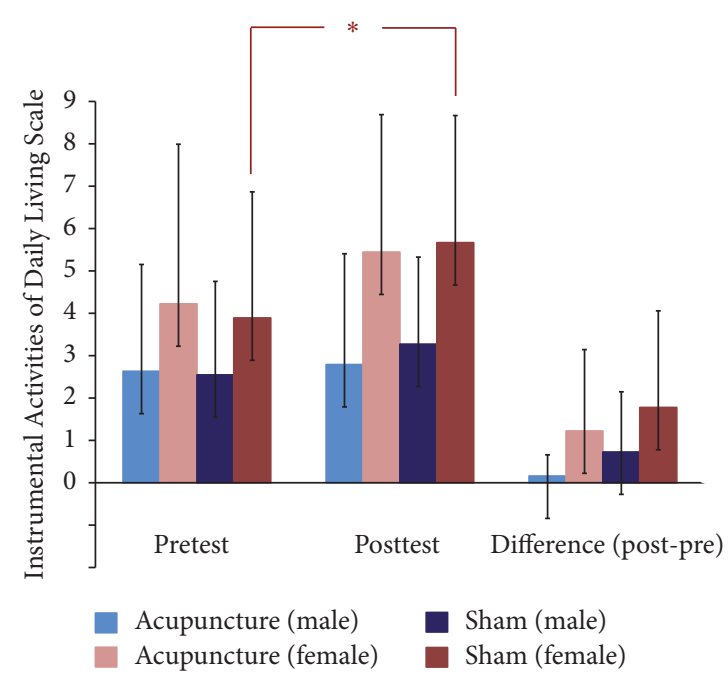

(c)

FIGURE 2: (a) Effect of acupuncture and sham acupuncture on BI, ${ }^{*} p<0.05$. (b) Effect of acupuncture and sham acupuncture on NIHSS, ${ }^{*} p<0.05$. (c) Effect of acupuncture and sham acupuncture on IADL, ${ }^{*} p<0.05$.

\section{Discussion}

In this study, we found no significant differences in change in NIHSS, BI, IADL, or HAM-D scores between patients who received real acupuncture and those who received sham treatment. The high drop-out rate is one of the possible causes for that finding. The attrition rate was estimated to be $20 \%$; however, the rates were $28.57 \%$ in the acupuncture group and $29.17 \%$ in the sham group. One of the reasons for the higher than expected attrition rates was the relatively high number of acupuncture sessions $(n=24)$ required to complete the trial. Patients who were transferred to other hospitals for western treatment during the trial might have found it inconvenient to return to the CMUH to receive our treatment due to either distance or time constraints and, therefore, dropped out of the study. Liu et al. found that acupuncture did not have a beneficial effect on stroke recovery and that the lack of effect might have been because the assessments of the effect were conducted too soon after the occurrence of stroke, in most cases 2-3 weeks after stroke [13]. That was the reason why we designed the trial to include 24 treatment sessions. Another possible reason for the lack of better effect of acupuncture on the majority of poststroke complications is that patients in both groups underwent conventional western rehabilitation and were given western medications as needed during inpatient admission and outpatient tracking, which may have introduced bias. In addition, the effect of western treatment might have masked or minimized the betweengroup differences in all scales. A third reason is due, at least in part, to our limited research resources; we were unable to 


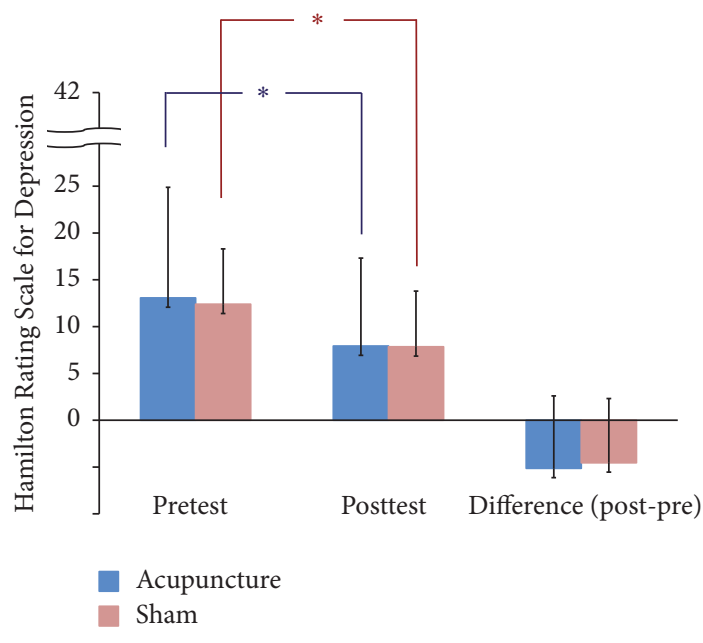

(a)

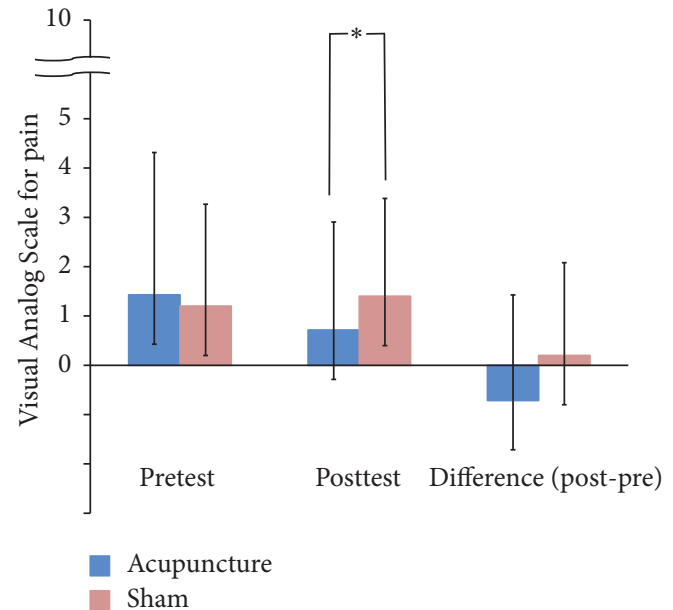

(b)

FIGURE 3: (a) Effect of acupuncture and sham acupuncture on HAM-D, ${ }^{*} p<0.05$. (b) Effect of acupuncture and sham acupuncture on VAS, ${ }^{*} p<0.05$.

TABLE 2: Comparison of NIHSS, Barthel Index, IADL, HAM-D, and VAS scores between two groups.

\begin{tabular}{|c|c|c|c|c|c|c|}
\hline \multirow{2}{*}{ Group assessment } & \multicolumn{2}{|c|}{ Acupuncture } & \multicolumn{2}{|c|}{ Sham } & \multicolumn{2}{|c|}{$p$ value (between-group) } \\
\hline & Pretest & Posttest & Pretest & Posttest & Pretest & Posttest \\
\hline NIHSS & $6.00 \pm 5.84$ & $3.82 \pm 4.95$ & $5.95 \pm 5.45$ & $3.55 \pm 4.63$ & 0.67 & 0.97 \\
\hline NIHSS difference & \multicolumn{2}{|c|}{$-2.18 \pm 3.32$} & \multicolumn{2}{|c|}{$-2.40 \pm 2.62$} & \multicolumn{2}{|c|}{0.59} \\
\hline Barthel Index & $59.64 \pm 41.94$ & $73.04 \pm 35.23$ & $65.75 \pm 34.08$ & $78.00 \pm 31.72$ & 0.93 & 0.60 \\
\hline BI difference & \multicolumn{2}{|c|}{$13.39 \pm 25.57$} & \multicolumn{2}{|c|}{$12.25 \pm 19.50$} & \multicolumn{2}{|c|}{0.40} \\
\hline IADL (male) & $2.63 \pm 2.52$ & $2.79 \pm 2.62$ & $2.55 \pm 2.21$ & $3.27 \pm 2.05$ & 1.00 & 0.70 \\
\hline IADL (male) difference & \multicolumn{2}{|c|}{$0.16 \pm 0.50$} & \multicolumn{2}{|c|}{$0.73 \pm 1.12$} & \multicolumn{2}{|c|}{0.42} \\
\hline IADL (female) & $4.22 \pm 3.77$ & $5.44 \pm 3.25$ & $3.89 \pm 2.98$ & $5.67 \pm 3.00$ & 1.00 & 0.93 \\
\hline IADL (female) difference & \multicolumn{2}{|c|}{$1.22 \pm 1.92$} & \multicolumn{2}{|c|}{$1.78 \pm 2.279$} & \multicolumn{2}{|c|}{0.73} \\
\hline HAM-D & $13.94 \pm 11.27$ & $6.22 \pm 6.61$ & $12.60 \pm 6.34$ & $6.53 \pm 5.80$ & 0.62 & 0.50 \\
\hline HAM-D difference & \multicolumn{2}{|c|}{$-7.72 \pm 8.37$} & \multicolumn{2}{|c|}{$-6.07 \pm 7.11$} & \multicolumn{2}{|c|}{0.97} \\
\hline VAS & $1.56 \pm 2.97$ & $0.44 \pm 1.83$ & $1.47 \pm 2.29$ & $1.73 \pm 2.15$ & 0.68 & $0.04^{*}$ \\
\hline VAS difference & \multicolumn{2}{|c|}{$-1.11 \pm 2.54$} & \multicolumn{2}{|c|}{$0.27 \pm 2.11$} & \multicolumn{2}{|c|}{0.53} \\
\hline
\end{tabular}

Wilcoxon signed rank test was used. ${ }^{*} p<0.05$.

NIHSS: National Institutes of Health Stroke Scale; BI: Barthel Index; IADL: Instrumental Activities of Daily Living; HAM-D: Hamilton Depression Rating Scale; VAS: Visual Analogue Scale for pain.

recruit enough patients to achieve the minimal sample size needed to detect significance of the intervention effect on the primary outcome measure, namely, change in NIHSS.

Two types of pain are common poststroke complications. One is central poststroke pain and the other is hemiplegic shoulder pain, which impacts the limb motor function, disturbs the rehabilitation process, extends the length of hospitalization, and affects the patient's quality of life. Because we excluded central poststroke pain at first, lots of the pain as our study showed are hemiplegic shoulder pain and fewer are pain from affected lower limbs. Previous study has shown that spastic symptoms can induce pain, ankylosis, tendon retraction, or muscle weakness [14]. Besides, hemiplegic shoulder pain affects $16-84 \%$ of impaired stroke survivors
[15]. Even though there are lots of therapies such as physiotherapy, massage, strapping, slings, intraarticular or subacromial corticosteroid injections, suprascapular nerve blocks, percutaneous or superficial electrical muscle stimulation, and intramuscular botulinum toxin type A injections, there is no specific evidence for most of these treatments [16]. Our trial focused on the pain caused by spasticity and showed that acupuncture is effective at reducing the severity of limb pain. Two recent systematic reviews also concluded that acupuncture is an effective treatment modality for poststroke shoulder pain [17] and spasticity [18]. The obvious betweengroup difference in posttest VAS scales might indirectly show that acupuncture results in a reduction in the degree of pain caused by spasticity. 
TABLE 3: Summary and comparison of randomized sham-controlled trials of acupuncture for global functional recovery after stroke (acute to subacute stage).

\begin{tabular}{|c|c|c|c|c|c|c|c|}
\hline Study & $\begin{array}{l}\text { Study } \\
\text { design }\end{array}$ & $\begin{array}{c}\text { Patient } \\
\text { population }\end{array}$ & $\begin{array}{l}\text { Experimental } \\
\text { treatment }\end{array}$ & $\begin{array}{l}\text { Control } \\
\text { treatment }\end{array}$ & $\begin{array}{l}\text { Therapist/session } \\
\text { of course }\end{array}$ & $\begin{array}{l}\text { Assessor/ITT or } \\
\text { PP/outcome measures }\end{array}$ & Intergroup differences \\
\hline $\begin{array}{l}\text { Naeser et } \\
\text { al. } 1992 \\
{[19]}\end{array}$ & $\begin{array}{l}\text { Double- } \\
\text { blind, } \\
\text { parallel } \\
\text { 2-arm }\end{array}$ & $\begin{array}{c}n=16, \\
1-3 \text { mth after } \\
\text { infarction } \\
\text { Fresh case? }\end{array}$ & $\begin{array}{l}\text { (A) }(n=10) \\
\text { Acupuncture + } \\
\text { elec- } \\
\text { troacupunc- } \\
\text { ture and scalp } \\
\text { acupuncture }\end{array}$ & $\begin{array}{l}\text { (B) }(n=6) \\
\text { Sham } \\
\text { acupuncture } \\
\text { (penetrating) + } \\
\text { sham electrical } \\
\text { stimulation } \\
\text { (electrical } \\
\text { stimulation not } \\
\text { conducted) }\end{array}$ & $\begin{array}{l}\text { Therapists? } \\
20 \text { times } \\
\text { Within } 4 \text { wks }\end{array}$ & $\begin{array}{l}3 \text { assessors not } \\
\text { belonging to ITT or } \\
\text { PP? } \\
\text { (1) Boston Motor } \\
\text { Inventory } \\
\text { (2) Boston Motor } \\
\text { Inventory with } \\
\text { analysis of CT scan of } \\
\text { lesion site }\end{array}$ & $\begin{array}{l}\text { Significantly } \\
\text { dependent on CT } \\
\text { scan lesion site }\end{array}$ \\
\hline $\begin{array}{l}\text { Gosman- } \\
\text { Hedström } \\
\text { et al. } 1998 \\
{[21]}\end{array}$ & $\begin{array}{l}\text { Single- } \\
\text { blind, } \\
\text { parallel } \\
\text { 3-arm }\end{array}$ & $\begin{array}{c}n=104, \\
<1 \text { wk after } \\
\text { stroke Fresh } \\
\text { case? }\end{array}$ & $\begin{array}{l}\text { (A) }(n=37) \\
\text { (electrical + } \\
\text { manual) } \\
\text { Acupuncture + } \\
\text { conventional } \\
\text { stroke } \\
\text { rehabilitation }\end{array}$ & $\begin{array}{l}(\mathrm{B})(n=34) \\
\text { Superficial } \\
\text { acupuncture, no } \\
\text { "de chi" + } \\
\text { conventional } \\
\text { stroke } \\
\text { rehabilitation } \\
(\mathrm{C})(n=33) \\
\text { Conventional } \\
\text { stroke } \\
\text { rehabilitation }\end{array}$ & $\begin{array}{l}4 \text { therapists } \\
20 \text { times } \\
\text { Within } 10 \text { wks }\end{array}$ & $\begin{array}{l}2 \text { assessor intention to } \\
\text { treat } \\
\text { (1) Scandinavian } \\
\text { Neurological Stroke } \\
\text { Scale } \\
\text { (2) Barthel ADL } \\
\text { Index } \\
\text { (3) Sunnaas ADL } \\
\text { Index } \\
\text { (4) Nottingham } \\
\text { Health Profile }\end{array}$ & Not significant \\
\hline
\end{tabular}

(A) $(n=48)$

Acupuncture +

elec-

troacupunc-

$\begin{array}{lcc} & \text { Single- } & n=150 \\ \text { Johansson } & \text { blind, } & 5 \sim 10 \mathrm{~d} \text { after } \\ \text { et al. 2001 } & \text { parallel } & \text { stroke Fresh } \\ \text { [22] } & \text { 3-arm } & \text { case? }\end{array}$

[22] 3-arm ture +

conventional

physiotherapy

(B) $(n=51)$

High-intensity,

low-frequency

TENS +

conventional

physiotherapy

Health Profile 
TABLE 3: Continued.

\begin{tabular}{|c|c|c|c|c|c|c|c|}
\hline Study & $\begin{array}{l}\text { Study } \\
\text { design }\end{array}$ & $\begin{array}{c}\text { Patient } \\
\text { population }\end{array}$ & $\begin{array}{l}\text { Experimental } \\
\text { treatment }\end{array}$ & $\begin{array}{l}\text { Control } \\
\text { treatment }\end{array}$ & $\begin{array}{c}\text { Therapist/session } \\
\text { of course }\end{array}$ & $\begin{array}{l}\text { Assessor/ITT or } \\
\text { PP/outcome measures }\end{array}$ & Intergroup differences \\
\hline $\begin{array}{l}\text { Hopwood } \\
\text { et al. } 2008 \\
{[24]}\end{array}$ & $\begin{array}{l}\text { Single- } \\
\text { blind, } \\
\text { parallel } \\
\text { 2-arm }\end{array}$ & $\begin{array}{c}n=105 \\
4-10 \mathrm{~d} \text { after } \\
\text { stroke Fresh } \\
\text { case }\end{array}$ & $\begin{array}{l}\text { (A) }(n=57) \\
\text { Acupuncture + } \\
\text { elec- } \\
\text { troacupunc- } \\
\text { ture and scalp } \\
\text { acupuncture }\end{array}$ & $\begin{array}{l}\text { (B) }(n=48) \\
\text { Sham TENS } \\
\text { (with no current } \\
\text { flow) }\end{array}$ & $\begin{array}{l}\text { therapists from } 5 \\
\text { general hospitals } \\
\text { in Hampshire } \\
\text { (UK) } 12 \text { times } \\
\text { Within } 4 \text { wks }\end{array}$ & $\begin{array}{l}\text { assessment nurses } \\
\text { intention to treat } \\
\text { (1) Barthel Index } \\
\text { (2) Motoricity Index } \\
\text { (3) Nottingham } \\
\text { Health Profile }\end{array}$ & $\begin{array}{l}\text { no significant } \\
\text { difference Except } \\
\text { improvement in the } \\
\text { MI }\end{array}$ \\
\hline $\begin{array}{l}\text { Shen et al. } \\
2012 \text { [11] }\end{array}$ & $\begin{array}{l}\text { Double- } \\
\text { blind, } \\
\text { parallel } \\
\text { 2-arm }\end{array}$ & $\begin{array}{c}n=290, \\
24 \text { hr-14d } \\
\text { after acute } \\
\text { ischemic } \\
\text { stroke Fresh } \\
\text { case }\end{array}$ & $\begin{array}{l}\text { (A) }(n=145) \\
\text { Acupuncture + } \\
\text { medical } \\
\text { treatment }\end{array}$ & $\begin{array}{l}(\mathrm{B})(n=145) \\
\text { Sham } \\
\text { acupuncture } \\
\text { (nearby the } \\
\text { acupoints) + } \\
\text { medical } \\
\text { treatment }\end{array}$ & $\begin{array}{l}\text { Therapists of } 4 \\
\text { hospitals } \\
28 \text { times } \\
\text { Within } 4 \text { wk }\end{array}$ & $\begin{array}{l}\text { A research nurse } \\
\text { ITT or PP? } \\
\text { (1) Barthel Index } \\
\text { (2) Relapse } \\
\text { (3) Death } \\
\text { (4) NIHSS } \\
\text { (5) Chinese Stroke } \\
\text { Scale } \\
\text { (6) Oxford Handicap } \\
\text { Scale } \\
\text { (7) Stroke Specific } \\
\text { Quality of Life Scale }\end{array}$ & $\begin{array}{l}\text { (1) } p=0.01 \\
\text { (2) } p=0.001 \\
\text { (3) } p=0.558 \\
\text { (4) } p<0.01 \\
\text { (5) } p<0.001 \\
\text { (6) Intervention }< \\
\text { control } \\
\text { (7) } p<0.01\end{array}$ \\
\hline
\end{tabular}

\begin{tabular}{|c|c|c|c|c|c|c|c|}
\hline $\begin{array}{l}\text { Zhu et al. } \\
2013 \text { [25] }\end{array}$ & $\begin{array}{l}\text { Single- } \\
\text { blind, } \\
\text { parallel } \\
\text { 2-arm }\end{array}$ & $\begin{array}{c}n=188 \\
<30 \mathrm{~d} \text { after } \\
\text { stroke Fresh } \\
\text { case }\end{array}$ & $\begin{array}{l}\text { (A) }(n=98) \\
\text { Acupuncture } \\
\text { (body and } \\
\text { scalp) }+ \\
\text { conventional } \\
\text { physiotherapy }\end{array}$ & $\begin{array}{l}\text { (B) }(n=90) \\
\text { Conventional } \\
\text { physiotherapy }\end{array}$ & $\begin{array}{c}\text { physiatrists? } \\
\text { From } 4 \\
\text { rehabilitation } \\
\text { centers } 42.6 \text { times } \\
\text { of body } \\
\text { acupuncture and } \\
22.5 \text { times of scalp } \\
\text { acupuncture } \\
\text { within } 3 \text { mths }\end{array}$ & $\begin{array}{l}4 \text { physiatrists } \\
\text { Intention to treat } \\
\text { (1) Fugl-Meyer } \\
\text { Assessment } \\
\text { (2) Barthel Index }\end{array}$ & $\begin{array}{l}\text { No significant } \\
\text { difference }\end{array}$ \\
\hline $\begin{array}{l}\text { Zhang et } \\
\text { al. } 2015 \\
{[12]}\end{array}$ & $\begin{array}{l}\text { Single- } \\
\text { blinded, } \\
\text { parallel } \\
2 \text {-arm }\end{array}$ & $\begin{array}{c}n=862 \\
3-10 \text { d after } \\
\text { ischemic } \\
\text { stroke Fresh } \\
\text { case? }\end{array}$ & $\begin{array}{l}\text { (A) }(n=427) \\
\text { Acupuncture } \\
\text { plus standard } \\
\text { care }\end{array}$ & $\begin{array}{l}(B)(n=435) \\
\text { Standard care }\end{array}$ & $\begin{array}{c}\text { Acupuncturists of } \\
\text { multicenter (40 } \\
\text { hospitals) } 20 \\
\text { times } \\
\text { Within } 4 \text { wks }\end{array}$ & $\begin{array}{l}\text { Assessors? } \\
\text { Intention to treat } \\
\text { (1) Scandinavian } \\
\text { Stroke Scale } \\
\text { (2) Barthel Index }\end{array}$ & $\begin{array}{l}\text { No significant } \\
\text { difference }\end{array}$ \\
\hline Our study & $\begin{array}{l}\text { Double- } \\
\text { blind, } \\
\text { parallel } \\
\text { 2-arm }\end{array}$ & $\begin{array}{c}n=52 \\
1 \sim 2 \mathrm{wk} \\
\text { After stroke } \\
\text { Fresh case }\end{array}$ & $\begin{array}{l}\text { (A) }(n=28) \\
\text { Acupuncture } \\
\text { (body and } \\
\text { scalp) }+ \\
\text { conventional } \\
\text { physiotherapy }\end{array}$ & $\begin{array}{l}\text { (B) }(n=24) \\
\text { Sham } \\
\text { acupuncture } \\
\text { (superficial, not } \\
\text { acupoints and } \\
\text { no "de chi") + } \\
\text { conventional } \\
\text { physiotherapy }\end{array}$ & $\begin{array}{l}1 \text { therapist, } 24 \\
\text { times } \\
\text { Within } 8 \mathrm{wks}\end{array}$ & $\begin{array}{l}1 \text { assessor } \\
\text { Intention to treat } \\
\text { (1) NIHSS } \\
\text { (2) Barthel Index } \\
\text { (3) Instrumental } \\
\text { Activities of Daily } \\
\text { Living } \\
\text { (4) Hamilton Rating } \\
\text { Scale for Depression } \\
\text { (5) Visual Analogue } \\
\text { Scale for pain }\end{array}$ & $\begin{array}{l}\text { (1) } p=0.97 \\
\text { (2) } p=0.60 \\
\text { (3) } p=0.70 \text { male } \\
p=0.93 \text { female } \\
\text { (4) } p=0.50 \\
\text { (5) } p=0.04\end{array}$ \\
\hline
\end{tabular}

TENS: transcutaneous electrical nerve stimulation; NIHSS: National Institutes of Health Stroke Scale; d: day; wk: week; mth: month.

World Health Organization Quality of Life BREF (WHOQOL-BREF); ITT: intention to treat; PP: per-protocol.

Furthermore, to highlight the value of our study, we searched for clinical trials of acupuncture for global functional recovery from acute to subacute stage of stroke conducted during the period 1992 to 2016 and identified nine studies with relatively good methodological quality. Table 3 provides a summary and comparison of these trials. Among those nine trials, three were adequately designed subjectand-assessor-blind studies with a low degree of performance bias $[11,19,20]$. In our subject-and-assessor-blind trial, we minimized potential bias by excluding patients with recurrent stroke, unlike the trials conducted by Naeser et al., Gosman-Hedström et al., Johansson et al., and Schuler et al. Furthermore, our use of only one therapist and one blind assessor further minimized treatment and detection bias. The number of acupuncture sessions in our study $(n=24)$ conducted over an eight-week period was markedly higher 
than in most other trials, allowing us to more accurately measure the accumulation effect of acupuncture on strokerelated complications. As in most of the previous trials on the effect of acupuncture in stroke patients, our trial used intention-to-treat to avoid attrition bias when analyzing data. In addition, as in most trials, we found that acupuncture resulted in modest improvement in some of the outcome measures, such as the Visual Analogue Scale for pain.

\section{Conclusion}

Acupuncture provided more effective poststroke pain relief than sham acupuncture treatment in the subacute phase of stroke. However, acupuncture was not superior to sham treatment for recovery of neurological function, activities of daily living, or depression. Further studies involving larger sample sizes and more treatment sessions are warranted.

\section{Abbreviations}

$\begin{array}{ll}\text { NIHSS: } & \text { National Institutes of Health Stroke Scale } \\ \text { BI: } & \text { Barthel Index } \\ \text { IADL: } & \text { Instrumental Activities of Daily Living } \\ \text { HAM-D: } & \text { Hamilton Depression Rating Scale } \\ \text { VAS: } & \text { Visual Analogue Scale for pain } \\ \text { SAE: } & \text { Severe Adverse Events } \\ \text { CMUH: } & \text { China Medical University Hospital. }\end{array}$

\section{Conflicts of Interest}

The authors declare no conflicts of interest.

\section{Acknowledgments}

This study was supported by China Medical University under the Aim for Top University Plan of the Ministry of Education, Taiwan, and The Taiwan Ministry of Health and Welfare Clinical Trial and Research Center of Excellence (MOHW105-TDU-B-212-133019).

\section{References}

[1] P. Langhorne, D. J. Stott, L. Robertson et al., "Medical complications after stroke: a multicenter study," Stroke, vol. 31, no. 6, pp. 1223-1229, 2000.

[2] L. Touma, K. B. Filion, L. H. Sterling, R. Atallah, S. B. Windle, and M. J. Eisenberg, "Stent retrievers for the treatment of acute ischemic stroke: a systematic review and meta-analysis of randomized clinical trials," JAMA Neurology, vol. 73, no. 3, pp. 275-281, 2016.

[3] The National Institute of Neurological Disorders and Stroke rtPA Stroke Study Group, "Tissue plasminogen activator for acute ischemic stroke," New England Journal of Medicine, vol. 333, no. 24, pp. 1581-1587, 1995.

[4] J. M. Wardlaw, V. Murray, E. Berge, and G. J. Del Zoppo, "Thrombolysis for acute ischaemic stroke," Cochrane Database of Systematic Reviews, no. 7, Article ID CD000213, 2009.

[5] J. C. Hemphill III, D. C. Bonovich, L. Besmertis, G. T. Manley, and S. C. Johnston, "The ICH score: a simple, reliable grading scale for intracerebral hemorrhage," Stroke, vol. 32, no. 4, pp. 891-897, 2001.

[6] S.-W. Park, S.-H. Yi, J. A. Lee, P. W. Hwang, H. C. Yoo, and K. S. Kang, "Acupuncture for the treatment of spasticity after stroke: a meta-analysis of randomized controlled trials," Journal of Alternative and Complementary Medicine, vol. 20, no. 9, pp. 672-682, 2014.

[7] J. C. Kong, M. S. Lee, B.-C. Shin, Y.-S. Song, and E. Ernst, "Acupuncture for functional recovery after stroke: a systematic review of sham-controlled randomized clinical trials," CMAJ, vol. 182, no. 16, pp. 1723-1729, 2010.

[8] F. K. Sze, E. Wong, K. K. Or, J. Lau, and J. Woo, "Does acupuncture improve motor recovery after stroke? A metaanalysis of randomized controlled trials," Stroke, vol. 33, no. 11, pp. 2604-2619, 2002.

[9] G.-C. Zhang, W.-B. Fu, N.-G. Xu et al., "Meta analysis of the curative effect of acupuncture on post-stroke depression," Journal of Traditional Chinese Medicine, vol. 32, no. 1, pp. 6-11, 2012.

[10] F. Liu, Z.-M. Li, Y.-J. Jiang, and L.-D. Chen, "A meta-analysis of acupuncture use in the treatment of cognitive impairment after stroke," Journal of Alternative and Complementary Medicine, vol. 20, no. 7, pp. 535-544, 2014.

[11] P.-F. Shen, L. Kong, L.-W. Ni et al., "Acupuncture intervention in ischemic stroke: a randomized controlled prospective study," American Journal of Chinese Medicine, vol. 40, no. 4, pp. 685693, 2012.

[12] S. Zhang, B. Wu, M. Liu et al., "Acupuncture efficacy on ischemic stroke recovery: multicenter randomized controlled trial in China," Stroke, vol. 46, no. 5, pp. 1301-1306, 2015.

[13] H. Liu, D. Zhang, X. Tan et al., "The effect of acupuncture on stroke recovery: Study protocol for a randomized controlled trial," BMC Complementary and Alternative Medicine, vol. 12, article 216, 2012.

[14] A. Thibaut, C. Chatelle, E. Ziegler, M.-A. Bruno, S. Laureys, and O. Gosseries, "Spasticity after stroke: physiology, assessment and treatment," Brain Injury, vol. 27, no. 10, pp. 1093-1105, 2013.

[15] H. Zhao, W. Nie, Y. Sun et al., "Warm needling therapy and acupuncture at meridian-sinew sites based on the meridiansinew theory: hemiplegic shoulder pain," Evidence-Based Complementary and Alternative Medicine, vol. 2015, Article ID 694973, 8 pages, 2015.

[16] J. M. Vasudevan and B. J. Browne, "Hemiplegic shoulder pain: an approach to diagnosis and management," Physical Medicine and Rehabilitation Clinics of North America, vol. 25, no. 2, pp. 411-437, 2014.

[17] J. A. Lee, S.-W. Park, P. W. Hwang et al., "Acupuncture for shoulder pain after stroke: a systematic review," Journal of Alternative and Complementary Medicine, vol. 18, no. 9, pp. 818823, 2012.

[18] S. M. Lim, J. Yoo, E. Lee et al., "Acupuncture for spasticity after stroke: a systematic review and meta-analysis of randomized controlled trials," Evidence-Based Complementary and Alternative Medicine, vol. 2015, Article ID 870398, 12 pages, 2015.

[19] M. A. Naeser, M. P. Alexander, D. Stiassny-Eder, V. Galler, J. Hobbs, and D. Bachman, "Real versus sham acupuncture in the treatment of paralysis in acute stroke patients: a CT Scan Lesion Site Study," Neurorehabilitation and Neural Repair, vol. 6, no. 4, pp. 163-174, 1992.

[20] J. Park, A. R. White, M. A. James et al., "Acupuncture for subacute stroke rehabilitation: a sham-controlled, subject- and assessor-blind, randomized trial," Archives of Internal Medicine, vol. 165, no. 17, pp. 2026-2031, 2005. 
[21] G. Gosman-Hedström, L. Claesson, U. Klingenstierna et al., "Effects of acupuncture treatment on daily life activities and quality of life: a controlled, prospective, and randomized study of acute stroke patients," Stroke, vol. 29, no. 10, pp. 2100-2108, 1998.

[22] B. B. Johansson, E. Haker, M. von Arbin et al., "Acupuncture and transcutaneous nerve stimulation in stroke rehabilitation: a randomized, controlled trial," Stroke, vol. 32, no. 3, pp. 707-713, 2001.

[23] M. S. Schuler, C. Durdak, N. M. Hösl et al., "Acupuncture treatment of geriatric patients with ischemic stroke: a randomized, double-controlled, single-blind study," Journal of the American Geriatrics Society, vol. 53, no. 3, pp. 549-550, 2005.

[24] V. Hopwood, G. Lewith, P. Prescott, and M. J. Campbell, "Evaluating the efficacy of acupuncture in defined aspects of stroke recovery: a randomised, placebo controlled single blind study," Journal of Neurology, vol. 255, no. 6, pp. 858-866, 2008.

[25] Y. Zhu, L. Zhang, G. Ouyang et al., "Acupuncture in subacute stroke: no benefits detected," Physical Therapy, vol. 93, no. 11, pp. 1447-1455, 2013. 


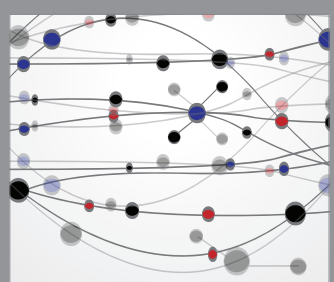

The Scientific World Journal
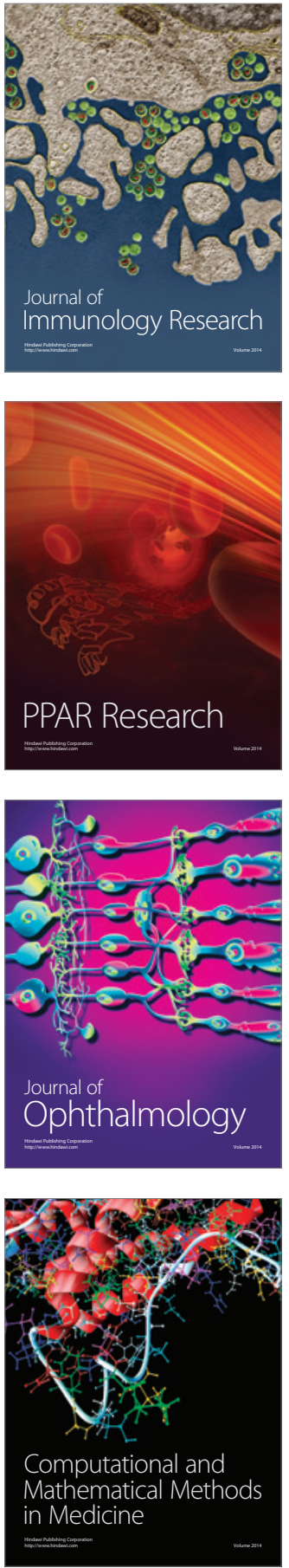

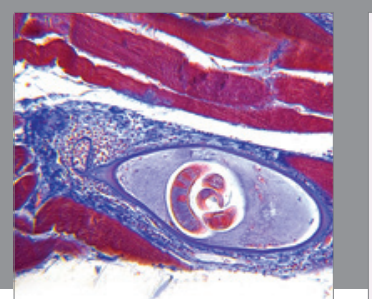

Gastroenterology Research and Practice
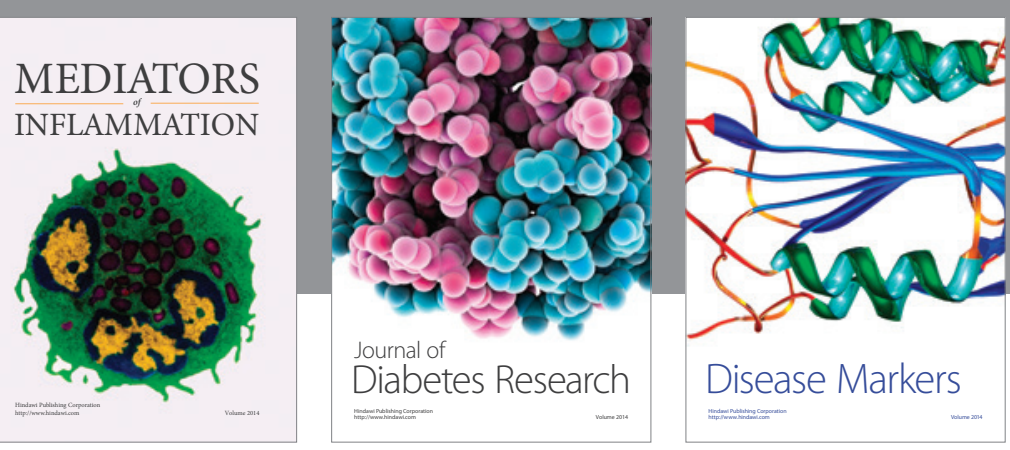

Disease Markers

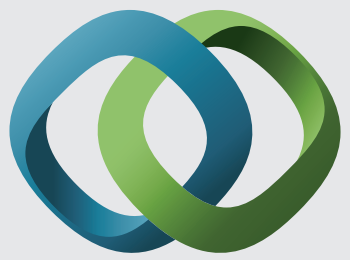

\section{Hindawi}

Submit your manuscripts at

https://www.hindawi.com
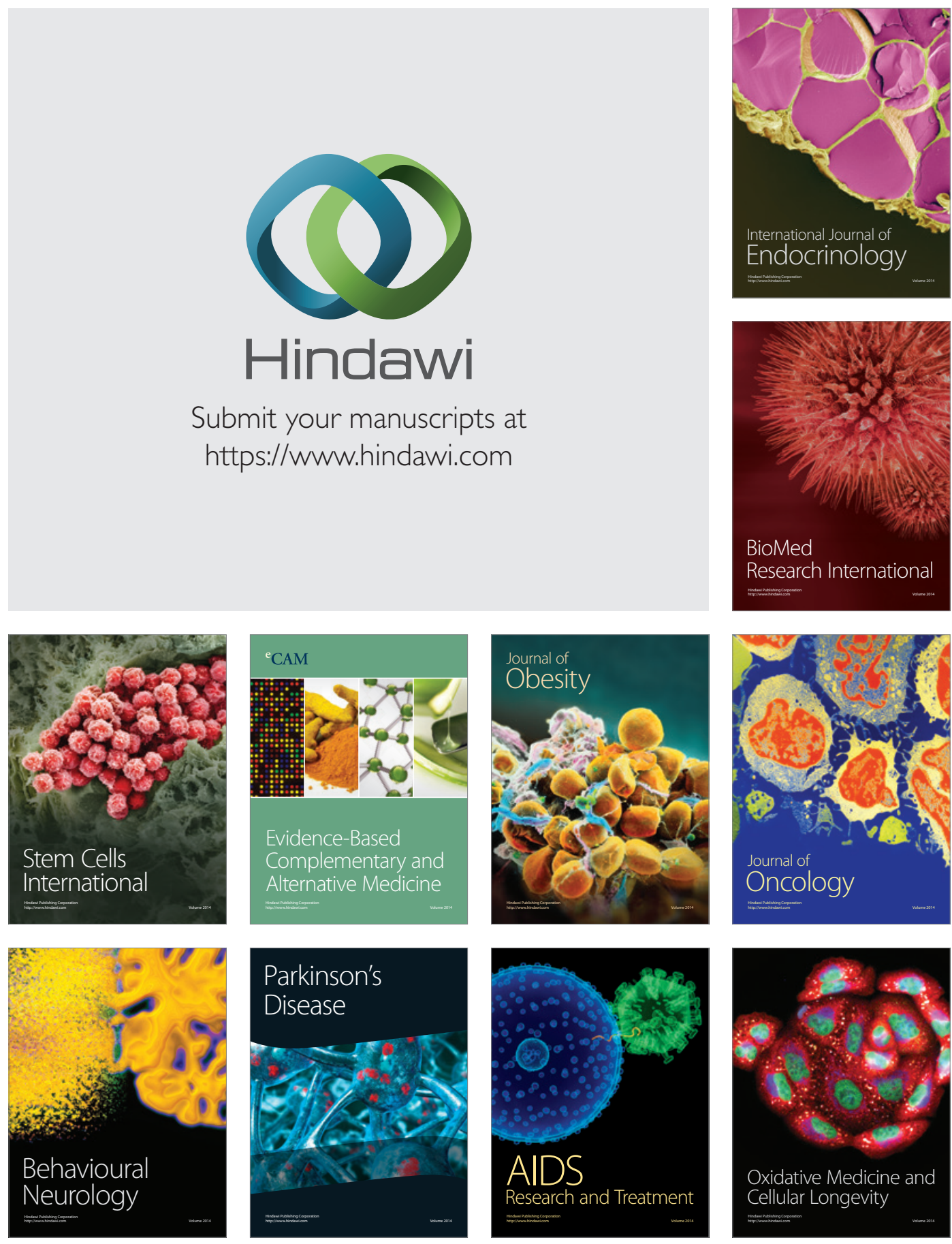